Research Article

\title{
EFFECT OF PHOSPHORUS AND MULCHING ON YIELD OF TOMATO
}

\author{
M.M.A. Mondal ${ }^{1}$ and M.I. Hoque ${ }^{2 *}$ \\ ${ }^{1}$ Crop Physiology Division, Bangladesh Institute of nuclear Agriculture \\ BAU Campus, Mymensingh-2202, Bangladesh \\ ${ }^{2}$ Plant Breeding Division, Bangladesh Institute of nuclear Agriculture \\ BAU Campus, Mymensingh-2202, Bangladesh
}

\begin{abstract}
The field experiment was carried out at Bangladesh Institute of Nuclear Agriculture, Mymensingh during October 2017 to March 2018 , to investigate the effect of different levels of phosphorus and mulches on growth, yield attributes and yield of tomato $\mathrm{cv}$. Roma VF. Two factors: (i) Four levels phosphorus viz., 0, 40, 80 and $120 \mathrm{~kg} \mathrm{P} \mathrm{ha}^{-1}$ and (ii) four different mulches viz., no mulch (control), water hyacinth, rice straw and banana leaves. The experiment was laid out in two factors randomized complete block design with four replications. The effect of phosphorus levels and mulches on morphological characters: plant height, leaf number plant $^{-1}$, reproductive characters: number of flower clusters plant ${ }^{-1}$, flowers plant $^{-1}$, days to flowering and yield contributing characters: number of fruits plant $^{-1}$, fruit length, single fruit weight and fruit yield both plant $^{-1}$ and ha $^{-1}$ was significant. The highest morphological and reproductive characters, yield contributing characters and fruit yield $\left(71.98 \mathrm{t} \mathrm{ha}^{-1}\right)$ were recorded in $120 \mathrm{~kg} \mathrm{P} \mathrm{ha}^{-1}$ followed by $80 \mathrm{~kg} \mathrm{P} \mathrm{ha}^{-1}$ $\left(69.76 \mathrm{t} \mathrm{ha}^{-1}\right)$ with same statistical rank. In contrast, the above morphological, reproductive, yield attributes and fruit yield $\left(47.62 \mathrm{t} \mathrm{ha}^{-1}\right)$ was recorded in control plant where no phosphorus was applied. Application of P @ $80 \mathrm{~kg} \mathrm{ha}^{-1}$ was found suitable dose for tomato cultivation. Among the three mulches, water hyacinth had remarkable effect on plant growth and yield attributes which resulting the highest fruit yield $\left(68.35 \mathrm{t} \mathrm{ha}^{-1}\right)$ in tomato. So, we may use water hyacinth mulch with application of $80 \mathrm{~kg} \mathrm{P}$ for maximizing tomato fruit yield during winter season for silty loam soil.
\end{abstract}

Keywords: Tomato, Phosphorus, Mulching, Yield, Fertilizer

\footnotetext{
*Corresponding author: apu.pstu@gmail.com
} 


\section{INTRODUCTION}

Tomato (Lycopersicon esculentum Mill.) is one of the popular and nutritious vegetable crops all over the world including Bangladesh. It contains vitamin A, B and $\mathrm{C}$ including calcium and carotene. The amount of nutrient is $1.98 \mathrm{~g}$ protein, $320 \mathrm{IU}$ vitamin-A, $1.8 \mathrm{mg}$ iron and $31 \mathrm{mg}$ vitamin-C in $100 \mathrm{~g}$ edible tomato (Parnell et al., 2004). Lycopene in tomato is a powerful antioxidant and reduces the risk of prostate cancer (Tegen et al., 2016).

Phosphorus (P) fertilizer occupies the second most important input after nitrogen for increasing crop production. Optimum level of $\mathrm{P}$ is essential for rapid root development and for good utilization of water and other nutrients by plant. $\mathrm{P}$ has pronounced effect on flower cluster production and the number of flowers that increases the yield of tomato (Zhang et al., 2007). Further many researchers reported that $\mathrm{P}$ fertilizer significantly increased the yield of tomato (Solaiman and Rabbani, 2006; Etissa et al., 2013, Kumar et al., 2013). The macronutrient fertilizers including P fertilizer consumption in Bangladesh are still below the level required for normal crop growth and development which resulted lower yield in tomato. To optimize the nutrient supply for proper growth and development of tomato crop, judicious fertilization is essential. Optimum rate of macronutrients including phosphorus not only increases the yield but also increase the quality of tomato (Kumar et al., 2013).

Mulching is a desirable management practice which is reported to regulate soil temperature, improve soil moisture, suppress weed growth and save labor cost (Kayum et al., 2008). The practice has been reported to increase yield by creating favorable temperature and moisture regimes in different parts of the world (Biswas et al., 2015). Water is the single factor which directly affects the tomato yield, because it contains $94 \%$ water. For successful crop about $285 \mathrm{~mm}$ water is required especially at flowering, fruit setting and enlargement stage (Jain et al., 2000). But irrigation facilities are not sufficient in all the regions of the country. Under the situation mulch play an important role in conserving soil moisture (Kayum et al., 2008). It improves the soil physical conditions by enhancing the biological activity of soil fauna and thus increases the soil fertility (Gordon et al., 2010). Artificial mulches with straw, rice husk, water hyacinth, crop residues or plastic mulch are generally practiced in the production of horticultural crops (Biswas et al., 2015). The present study was undertaken to assess the optimum level of phosphorus and to determine suitable mulch for maximum production of tomato.

\section{MATERIAL AND METHODS}

The field experiment was carried out at the Research Farm of the Bangladesh Institute of Nuclear Agriculture, Mymensingh during the period from October 2017 to March 2018. The selected site was a medium high land and the $\mathrm{pH}$ of the soil was 6.4 with organic matter content of $1.21 \%$. The analytical data of the soil sample from the experimental area was organic matter $1.67 \%, \mathrm{~N} 0.09 \%$, available $\mathrm{P}$ 
4.81ppm, exchangeable K $0.27 \mathrm{me} / 100 \mathrm{~g}$ and available $\mathrm{S} 13.9 \mathrm{ppm}$. The tomato variety Roma-VF was used as planting material in the experiment. The experiment consisted of two factors: Factor A: Four different levels of phosphorus such as 0, 40, 80 and $120 \mathrm{~kg} \mathrm{ha}^{-1}$ and Factor B: three mulches such as water hyacinth, rice straw and banana leaves. The experiment was laid out in two factors randomized complete block design with four replications. Seeds were sown in seedbed on 29 October 2017 and 27-day old seedlings were transplanted in the experimental field with recommended spacing of $50 \mathrm{~cm} \times 50 \mathrm{~cm}$. The unit plot size was $4 \mathrm{~m} \times 3 \mathrm{~m}$. Urea, muriate of potash (MoP), gypsum and cow dung were applied at the rate of $280 \mathrm{~kg}$ $\mathrm{ha}^{-1}, 180 \mathrm{~kg} \mathrm{ha}^{-1}, 80 \mathrm{~kg} \mathrm{ha}^{-1}$ and $10000 \mathrm{~kg} \mathrm{ha}^{-1}$, respectively (BARC, 2012). The triple superphosphate (TSP) was applied according to treatment. Whole amount of TSP, gypsum and half of MoP were applied as basal dose during final land preparation, cow dung also applied before 10 days of final land preparation. The remaining half of MoP was applied as top dressing at 45 days after transplanting (DAT). Half of urea was applied as top dress at 21 DAT and remaining half was applied at 45 DAT. Weeding, pruning, staking, pesticides spray and other intercultural operations were done when required.The first trip irrigation was given 30 days after planting (DAP) followed by irrigation at 45 DAT. Mulching was also done after second irrigation at appropriate time by breaking the soil crust.At harvest, ten plants from each plot were selected randomly for data recording on morphological and reproductive characters, yield and yield related traits. Fruit yield was collected from each plot excluding border line and converted into $\mathrm{t} \mathrm{ha}{ }^{-1}$. Harvesting was done at different dates depending on fruit ripening. The collected data were analyzed statistically following the analysis of variance (ANOVA) technique and the mean differences among treatments were compared by Duncan's Multiple Range Test (DMRT) using the statistical computer package program, MSTAT-C (Russell, 1986).

\section{RESULTS AND DISCUSSION}

The effect of phosphorus (P) on morphological characters such as plant height, number of leaves plant ${ }^{-1}$, reproductive characters such as number of flower clusters and flowers plant ${ }^{-1}$, number of flowers cluster $^{-1}$, days to flowering was significant (Table 1). Results showed that morphological and reproductive characters were higher in phosphorus applied plants than control plants. This result indicates that $\mathrm{P}$ has tremendous effect on growth and development in tomato. Results further revealed that plant height, number of leaves, flower clusters and flowers plant ${ }^{-1}$ increased significantly with increasing P levels till $80 \mathrm{~kg} \mathrm{ha}^{-1}$ and further increasing P levels did not increase significantly whereas reverse trend was observed in days required to flowering. The highest plant height $(76.1 \mathrm{~cm})$, number of flower clusters plant ${ }^{-1}$ (21.20) and flower number plant ${ }^{-1}(133.5)$ was recorded in $120 \mathrm{~kg} \mathrm{P} \mathrm{ha}^{-1}$ followed by $80 \mathrm{~kg} \mathrm{P} \mathrm{ha}^{-1}$ with same statistical rank. In contrast, the shortest plant $(63.4 \mathrm{~cm})$, the lowest number of leaves (35.43 plant $\left.^{-1}\right)$, flower clusters plant ${ }^{-1}(15.14)$ and flowers plant $^{-1}$ (76.76), longest days required to start flowering (32.55 days) was recorded in 
control plot. In control plot phosphorus was not sufficient for normal plant growth and development and resulted in reduction of number of leaves plant ${ }^{-1}$. This result is in agreement with that of Etissa et al. (2013) who reported that plant height and leaves number increased in applied plants than control plants.

Table 1. Effect of phosphorus levels and mulches on morphological and reproductive characters in tomato cv. Roma VF

\begin{tabular}{lcccccc}
\hline Treatment & $\begin{array}{c}\text { Plant } \\
\text { height } \\
(\mathrm{cm})\end{array}$ & $\begin{array}{c}\text { Leaves } \\
\text { plant }^{-1} \\
(\text { no. })\end{array}$ & $\begin{array}{c}\text { Days } \\
\text { to } \\
\text { flowering }\end{array}$ & $\begin{array}{c}\text { Flower } \\
\text { clusters } \\
\text { plant }^{-1}(\text { no. })\end{array}$ & $\begin{array}{c}\text { Flowers } \\
\text { cluster }^{-1} \\
(\text { no. })\end{array}$ & $\begin{array}{c}\text { Flowers } \\
\text { plant }^{-1} \\
(\text { no. })\end{array}$ \\
\hline $\begin{array}{l}\text { P levels } \\
\left(\mathrm{kg} \mathrm{ha}^{-1}\right)\end{array}$ & & & & & & \\
\hline 0 & $63.4 \mathrm{c}$ & $35.43 \mathrm{c}$ & $32.55 \mathrm{a}$ & $15.14 \mathrm{c}$ & $5.07 \mathrm{c}$ & $76.76 \mathrm{c}$ \\
40 & $69.6 \mathrm{~b}$ & $42.91 \mathrm{~b}$ & $29.83 \mathrm{~b}$ & $17.89 \mathrm{~b}$ & $6.08 \mathrm{~b}$ & $92.87 \mathrm{~b}$ \\
80 & $75.0 \mathrm{a}$ & $50.96 \mathrm{a}$ & $25.85 \mathrm{c}$ & $20.42 \mathrm{a}$ & $7.07 \mathrm{a}$ & $126.4 \mathrm{a}$ \\
120 & $76.1 \mathrm{a}$ & $50.70 \mathrm{a}$ & $25.75 \mathrm{c}$ & $21.20 \mathrm{a}$ & $7.10 \mathrm{a}$ & $133.5 \mathrm{a}$ \\
F-test & $* *$ & $* *$ & $* *$ & $* *$ & $* *$ & $* *$ \\
Mulches & & & & & & \\
No mulch & $66.4 \mathrm{~b}$ & $36.90 \mathrm{~b}$ & $29.44 \mathrm{a}$ & $16.21 \mathrm{~b}$ & $5.65 \mathrm{~b}$ & $81.59 \mathrm{c}$ \\
Water hyacinth & $74.5 \mathrm{a}$ & $48.65 \mathrm{a}$ & $27.10 \mathrm{~b}$ & $20.40 \mathrm{a}$ & $6.59 \mathrm{a}$ & $124.4 \mathrm{a}$ \\
Rice straw & $71.9 \mathrm{a}$ & $48.51 \mathrm{a}$ & $26.91 \mathrm{~b}$ & $19.3 \mathrm{a}$ & $6.55 \mathrm{a}$ & $116.4 \mathrm{a}$ \\
Banana leaves & $69.3 \mathrm{ab}$ & $46.00 \mathrm{a}$ & $26.80 \mathrm{~b}$ & $18.70 \mathrm{ab}$ & $6.49 \mathrm{a}$ & $105.9 \mathrm{~b}$ \\
F-test & $*$ & $* *$ & $* *$ & $* *$ & $* *$ & $* *$ \\
\hline
\end{tabular}

Figure (s) in a column, within treatment indicate do not differ significantly at $\mathrm{P} \leq 0.05$; ** and * indicate significant at $1 \%$ and $5 \%$ level of probability, respectively.

Use of different mulches had significant influence on morphological characters i.e. plant height, number of leaves plant ${ }^{-1}$, and reproductive characters such as number flower clusters and flowers plant ${ }^{-1}$, number of flowers cluster $^{-1}$ (Table 1). Result indicated that morphological and reproductive characters were higher in mulches plots over non-mulch plots. The plant height and leaf number were higher in mulches than control because of might be moisture percentage was higher in those mulches plots compared to control plot. It increased nutrient availability and plants uptake more nutrients resulting higher growth and development (Biswas et al., 2015). Among the mulches, the tallest plant $(74.5 \mathrm{~cm})$, the highest number of leavesplant ${ }^{-1}$ (48.65), flower cluster plant ${ }^{-1}$ (20.40) and flowers plant ${ }^{-1}$ (124.4.92) was recorded in water hyacinth mulch followed by rice straw and the lowest was recorded in no mulch. The highest flower number was recorded in water hyacinth and rice straw mulches due to production of highest flower clusters plant ${ }^{-1}$ (Table 1). However, the 
shortest plant $(66.4 \mathrm{~cm})$ and the lowest number of leaves plant $^{-1}(36.90)$ as well as flower cluster number and flowers number plant $^{-1}(81.59)$ was recorded in control plot. In control plot, soil moisture was may be less than the mulches plots that causes lesser amount of nutrient availability (Tegen et al., 2016). As a result, plant growth and development hampered and ultimately plant height was short. The highest plant height was observed in water hyacinth mulch than the other mulches as reported by Singh et al. (2006) in tomato which supported the present experimental result.

The effect of $\mathrm{P}$ levels on yield contributing characters such as number of fruits plant $^{-1}$, fruit length and single fruit weight and fruit yield both plant $^{-1}$ and ha ${ }^{-1}$ was significant (Table 2). Results revealed that yield contributing characters were higher in $\mathrm{P}$ applied plants over control plants. The number of fruits plant $^{-1}$, fruit length, single fruit weight and fruit yield increased with increasing $\mathrm{P}$ levels. However, application of $\mathrm{P}$ at the rate of $120 \mathrm{~kg} \mathrm{ha}^{-1}$, the yield contributing characters increased non-significantly over $80 \mathrm{~kg} \mathrm{ha}^{-1} \mathrm{P}$. The highest fruit number plant ${ }^{-1}$ (34.07), fruit length $(7.20 \mathrm{~cm})$, single fruit weight $(62.24 \mathrm{~g})$, fruit weight plant $^{-1}(1.91 \mathrm{~kg})$ and fruit yield ha $\mathrm{ha}^{-1}\left(71.98 \mathrm{t}\right.$ ) was recorded in $120 \mathrm{~kg} \mathrm{P} \mathrm{ha}^{-1}$ followed by $80 \mathrm{~kg} \mathrm{P}^{-1}$ with same statistical rank. This result indicates that $80 \mathrm{~kg} \mathrm{P} \mathrm{ha}^{-1}$ is sufficient for getting maximum fruits plant ${ }^{-1}$ in tomato. The lowest number of fruits plant $^{-1}$ (24.24), smallest fruit size and lowest fruit yield $\left(1.19 \mathrm{~kg} \mathrm{plant}^{-1}\right.$ and $\left.47.62 \mathrm{tha}^{-1}\right)$ was recorded in control plot due to production of lowest flower cluster and fruits plant ${ }^{-1}$. The lowest number of fruits plant ${ }^{-1}$ was recorded in control plot due to insufficient $\mathrm{P}$ for normal plant growth and development and resulted in reduction of number of fruits plant $^{-1}$. This result is in full agreement with that of Kumar et al. (2013) who stated that the number of fruits plant ${ }^{-1}$ increased with increasing phosphorous levels from 50 to $150 \mathrm{~kg} \mathrm{ha}^{-1}$ in tomato. Similar result was also reported by many workers (Groot et al., 2004; Nawaz et al., 2012; Etissa et al., 2013) in tomato. The highest fruit yield was found in 120 and $80 \mathrm{~kg} \mathrm{P} \mathrm{ha}^{-1}$ applied plants due to production of highest number of flower cluster and fruits plant ${ }^{-1}$ (Table 2).

Use of different mulches had significant influence on yield attributes and fruit yield of tomato over control (Table 2). Among the mulches, the highest fruit yield was recorded in water hyacinth mulch $\left(1.98 \mathrm{~kg}\right.$ plant $^{-1}$ and $\left.68.35 \mathrm{t} \mathrm{ha}^{-1}\right)$ followed by rice straw mulch $\left(1.92 \mathrm{~kg} \mathrm{plant}^{-1}\right.$ and $\left.64.60 \mathrm{t} \mathrm{ha}^{-1}\right)$. The highest fruit yield was recorded in water hyacinth mulch due to production of highest number of fruits plant ${ }^{-1}$. Further, among the mulches, banana leaves mulch performed the lowest in case of yield attributes and yield in tomato. However, within the mulch treatments, there had no significant different in single fruit weight. The lowest yield attributes and fruit yield was recorded in control plot. 
Table 2. Effect of phosphorus levels and mulches on yield attributes and fruit yield in tomato cv. Roma VF

\begin{tabular}{|c|c|c|c|c|c|}
\hline Treatments & $\begin{array}{l}\text { Fruits plant }{ }^{-1} \\
\text { (no.) }\end{array}$ & $\begin{array}{l}\text { Fruit } \\
\text { length } \\
(\mathrm{cm})\end{array}$ & $\begin{array}{l}\text { Single fruit } \\
\text { weight } \\
\text { (g) }\end{array}$ & $\begin{array}{l}\text { Fruit weight } \\
\text { plant }^{-1} \\
(\mathrm{~kg})\end{array}$ & $\begin{array}{l}\text { Fruit yield } \\
\qquad\left(\mathrm{t} \mathrm{ha}^{-1}\right)\end{array}$ \\
\hline \multicolumn{6}{|l|}{$\begin{array}{l}\text { P levels } \\
\left(\mathrm{kg} \mathrm{ha}^{-1}\right)\end{array}$} \\
\hline 0 & $24.24 \mathrm{c}$ & $5.04 \mathrm{c}$ & $54.28 \mathrm{c}$ & $1.32 \mathrm{c}$ & $47.62 \mathrm{c}$ \\
\hline 40 & $29.25 \mathrm{~b}$ & $6.41 \mathrm{~b}$ & $59.26 \mathrm{~b}$ & $1.54 \mathrm{~b}$ & $58.65 \mathrm{~b}$ \\
\hline 80 & $33.00 \mathrm{ab}$ & $7.18 \mathrm{a}$ & $61.80 \mathrm{ab}$ & $1.82 \mathrm{a}$ & $69.76 \mathrm{a}$ \\
\hline 120 & $34.07 \mathrm{a}$ & $7.20 \mathrm{a}$ & $62.24 \mathrm{a}$ & $1.91 \mathrm{a}$ & $71.98 \mathrm{a}$ \\
\hline F-test & $* *$ & $* *$ & $* *$ & $* *$ & $* *$ \\
\hline \multicolumn{6}{|l|}{ Mulches } \\
\hline No mulch & $27.37 \mathrm{c}$ & $5.84 \mathrm{c}$ & $57.78 \mathrm{~b}$ & $1.60 \mathrm{~b}$ & $53.75 \mathrm{~d}$ \\
\hline Water hyacinth & $32.56 \mathrm{a}$ & $6.80 \mathrm{a}$ & $60.38 \mathrm{a}$ & $1.98 \mathrm{a}$ & $68.35 \mathrm{a}$ \\
\hline Rice straw & $31.11 \mathrm{ab}$ & $6.69 \mathrm{ab}$ & $59.73 \mathrm{a}$ & $1.92 \mathrm{a}$ & $64.60 \mathrm{~b}$ \\
\hline Banana leaves & $29.51 \mathrm{abc}$ & $6.52 \mathrm{~b}$ & $59.70 \mathrm{a}$ & $1.78 \mathrm{a}$ & $61.30 \mathrm{c}$ \\
\hline F-test & $* *$ & $* *$ & $*$ & $* *$ & $* *$ \\
\hline
\end{tabular}

Figure (s) in a column, within treatment indicate do not differ significantly at $\mathrm{P} \leq 0.05$;

$* *$ and $*$ indicate significant at $1 \%$ and $5 \%$ level of probability, respectively.

Table 3. Combined effect of phosphorus levels and different mulches on yield attributes and fruit yield in tomato cv. Roma VF

\begin{tabular}{lccccc}
\hline $\begin{array}{c}\text { Interaction } \\
\text { ( level } \times \\
\text { mulches })\end{array}$ & $\begin{array}{c}\text { Fruits } \\
\text { plant }^{-1} \\
(\text { no. })\end{array}$ & $\begin{array}{c}\text { Fruit } \\
\text { length } \\
(\mathrm{cm})\end{array}$ & $\begin{array}{c}\text { Single fruit } \\
\text { weight } \\
(\mathrm{g})\end{array}$ & $\begin{array}{c}\text { Fruit weight } \\
\text { plant }^{-1} \\
(\mathrm{~kg})\end{array}$ & $\begin{array}{c}\text { Fruit yield } \\
\left(\mathrm{t} \mathrm{ha}^{-1}\right)\end{array}$ \\
\hline $\mathrm{P}_{0} \mathrm{M}_{0}$ & $21.68 \mathrm{~h}$ & $4.55 \mathrm{~h}$ & $51.73 \mathrm{f}$ & $1.12 \mathrm{e}$ & $40.32 \mathrm{~h}$ \\
$\mathrm{P}_{0} \mathrm{M}_{1}$ & $25.58 \mathrm{~g}$ & $5.35 \mathrm{f}$ & $55.28 \mathrm{e}$ & $1.41 \mathrm{~d}$ & $50.76 \mathrm{~g}$ \\
$\mathrm{P}_{0} \mathrm{M}_{2}$ & $25.55 \mathrm{~g}$ & $5.23 \mathrm{fg}$ & $55.22 \mathrm{e}$ & $1.41 \mathrm{~d}$ & $51.50 \mathrm{~g}$ \\
$\mathrm{P}_{0} \mathrm{M}_{3}$ & $24.15 \mathrm{gh}$ & $5.02 \mathrm{~g}$ & $54.92 \mathrm{e}$ & $1.33 \mathrm{de}$ & $47.88 \mathrm{~g}$ \\
$\mathrm{P}_{40} \mathrm{M}_{0}$ & $26.46 \mathrm{~g}$ & $5.96 \mathrm{e}$ & $57.92 \mathrm{de}$ & $1.53 \mathrm{~d}$ & $49.57 \mathrm{~g}$ \\
$\mathrm{P}_{40} \mathrm{M}_{1}$ & $31.48 \mathrm{cde}$ & $6.75 \mathrm{c}$ & $60.33 \mathrm{bc}$ & $1.90 \mathrm{c}$ & $64.98 \mathrm{de}$ \\
$\mathrm{P}_{40} \mathrm{M}_{2}$ & $30.30 \mathrm{def}$ & $6.60 \mathrm{c}$ & $59.46 \mathrm{~cd}$ & $1.80 \mathrm{c}$ & $61.56 \mathrm{ef}$ \\
$\mathrm{P}_{40} \mathrm{M}_{3}$ & $28.76 \mathrm{ef}$ & $6.40 \mathrm{~d}$ & $59.32 \mathrm{~cd}$ & $1.71 \mathrm{c}$ & $58.48 \mathrm{f}$
\end{tabular}




\begin{tabular}{lccccc}
\hline $\begin{array}{c}\text { Interaction } \\
(\mathrm{P} \text { level } \times \\
\text { mulches })\end{array}$ & $\begin{array}{c}\text { Fruits } \\
\text { plant }^{-1} \\
(\text { no. })\end{array}$ & $\begin{array}{c}\text { Fruit } \\
\text { length } \\
(\mathrm{cm})\end{array}$ & $\begin{array}{c}\text { Single fruit } \\
\text { weight } \\
(\mathrm{g})\end{array}$ & $\begin{array}{c}\text { Fruit weight } \\
\text { plant }^{-1} \\
(\mathrm{~kg})\end{array}$ & $\begin{array}{c}\text { Fruit yield } \\
\left(\mathrm{t} \mathrm{ha}^{-1}\right)\end{array}$ \\
\hline $\mathrm{P}_{80} \mathrm{M}_{0}$ & $30.14 \mathrm{def}$ & $6.37 \mathrm{~d}$ & $60.35 \mathrm{bc}$ & $1.82 \mathrm{c}$ & $62.24 \mathrm{ef}$ \\
$\mathrm{P}_{80} \mathrm{M}_{1}$ & $36.20 \mathrm{ab}$ & $7.55 \mathrm{ab}$ & $62.70 \mathrm{ab}$ & $2.27 \mathrm{a}$ & $77.63 \mathrm{ab}$ \\
$\mathrm{P}_{80} \mathrm{M}_{2}$ & $34.00 \mathrm{abc}$ & $7.47 \mathrm{ab}$ & $62.05 \mathrm{ab}$ & $2.11 \mathrm{~b}$ & $72.16 \mathrm{c}$ \\
$\mathrm{P}_{80} \mathrm{M}_{3}$ & $31.62 \mathrm{~cd}$ & $7.35 \mathrm{ab}$ & $61.94 \mathrm{ab}$ & $1.96 \mathrm{c}$ & $67.03 \mathrm{~d}$ \\
& $31.20 \mathrm{de}$ & $6.48 \mathrm{~cd}$ & $61.10 \mathrm{ab}$ & $1.91 \mathrm{c}$ & $62.88 \mathrm{de}$ \\
$\mathrm{P}_{120} \mathrm{M}_{0}$ & $37.00 \mathrm{a}$ & $7.60 \mathrm{a}$ & $63.22 \mathrm{a}$ & $2.34 \mathrm{a}$ & $80.03 \mathrm{a}$ \\
$\mathrm{P}_{120} \mathrm{M}_{1}$ & $34.57 \mathrm{abc}$ & $7.45 \mathrm{ab}$ & $62.09 \mathrm{ab}$ & $2.14 \mathrm{ab}$ & $73.19 \mathrm{bc}$ \\
$\mathrm{P}_{120} \mathrm{M}_{2}$ & $33.51 \mathrm{bcd}$ & $7.31 \mathrm{ab}$ & $62.60 \mathrm{ab}$ & $2.10 \mathrm{~b}$ & $71.82 \mathrm{c}$ \\
$\mathrm{P}_{120} \mathrm{M}_{3}$ & $*$ & $*$ & $*$ & $*$ & $*$ \\
F-test & & & $*$ & $*$ & \\
\hline
\end{tabular}

* indicate significant at 5\% level of probability; $\mathrm{P}_{0}=0 \mathrm{~kg} \mathrm{Pha}^{-1} ; \mathrm{P}_{40}=40 \mathrm{~kg} \mathrm{Pha}^{-1} ; \mathrm{P}_{80}=80 \mathrm{~kg} \mathrm{Pha}^{-1}$; $\mathrm{P}_{120}=120 \mathrm{~kg} \mathrm{Pha}^{-1} ; \mathrm{M}_{0}=$ No mulch; $\mathrm{M}_{1}=$ Water hyacinth; $\mathrm{M}_{2}=$ Rice straw; $\mathrm{M}_{3}=$ Banana leaves.

The combined effect of phosphorus level and mulches had significant effect on fruit number, fruit length, single fruit weight and fruit yield both plant ${ }^{-1}$ and ha $^{-1}$ in tomato (Table 3). The highest yield attributes were observed in the treatment combination of $120 \mathrm{~kg} \mathrm{P} \mathrm{ha}{ }^{-1}$ with water hyacinth mulch which resulted highest fruit yield in tomato. The lowest number of fruits plant ${ }^{-1}$ and fruit yield both plant ${ }^{-1}$ and ha $^{-1}$ was observed in control plot.

\section{CONCLUSION}

Tomato growth and yield were affected by different levels of phosphorus application and use of mulches. Application of P @ $80 \mathrm{~kg} \mathrm{ha}^{-1}$ was found suitable dose for tomato cultivation. Among the three mulches, water hyacinth had remarkable effect on plant growth and yield attributes which resulting the highest fruit yield in tomato. So, we may use water hyacinth mulch with application of $80 \mathrm{~kg} P$ for maximizing tomato fruit yield during winter season for silty loam soil.

\section{REFERENCES}

Biswas, S.K., Akanda, A.R. Rahman, M.S. and Hossain, M.A. (2015). Effect of drip irrigation and mulching on yield, water-use efficiency and economics of tomato. Plant Soil and Environment, 61 (3):97-102.

BARC. (2012). Fertilizer Recommendation guide. Bangladesh Agricultural Research Council (BARC). Farmgate, Dhaka-1215. Pp.72.

Etissa, E., Dechassa, N., Alamirew, T.Y., Alemayehu and Desalegn, L. (2013). Growth and yield components of tomato as influenced by nitrogen and phosphorus fertilizer applications in different growing seasons. Ethiopian Journal of Agricultural Science, 23:57-77. 
Gordon, G.G., Foshee, G.W., Reed, S.T., Brown, J.E. and Vinson, E.L. (2010). The effects of colored plastic mulches and row covers on the growth and yield of okra. Horticultural Technology, 20 (1):224-233.

Groot, C.C.de., Marcelis, L.F.M., Boogard, R. and Lambers, H. (2004). Response of growth of tomato to phosphorus and nitrogen nutrition. Acta Horticulturae, 633:357-364.

Jain, N., Chauhan, H.S., Singh, P.K. and Shukla, K.N. (2000). Response of tomato under drip irrigation and plastic mulching. In: Proceeding of the 6th International Micro-irrigation Congress, Micro-irrigation Technology for Developing Agriculture, South Africa. Pp. 45-51.

Kayum, M.A., Asaduzzaman, M. and Haque, M.Z. (2008). Effects of indigenous mulches on growth and yield of tomato. Journal of Agriculture and Rural Development, 6(12):1-6.

Kumar, M., Meena, M.L., Kumar, S., Sutanu, M. and Kumar, D. (2013). Effect of nitrogen, phosphorus and potassium fertilizers on the growth, yield and quality of tomatovar. Azad T-6. The Asian Journal of Horticulture, 8(2):616-619.

Nawaz, H., Zubair, M. and Derawadan, H. (2012). Interactive effects of nitrogen, phosphorus and zinc on growth and yield of Tomato. African Journal of Agricultural Research, 7(26):3792-3769.

Parnell, T.L., Suslow, Trevor, V. and Harris, L. J. (2004). "Tomatoes: Safe Methods to Store, Preserve, and Enjoy. ANR Catalog, University of California: Division of Agriculture and Natural Resources. Pp. 1-15.

Russell, D.F. (1986). MSTAT-C computer package programme. Crop and Soil Science Department, Michigan State Univ., USA.

Singh, I.S., Awasthi, O.P. and Meena, S.R. (2006). Influence of mulch on soil hydrothermal regime, growth and fruit yield of tomato grown under arid ecosystem. Agropedology Journal, 16: 112-116.

Solaiman, A.R.M. and Rabbani, M.G. (2006). Effects of NPKS and cow dung on growth and yield of tomato. Bulletin of the Institute of Tropical Agriculture, Kyushu University. Pp. 31-37.

Tegen, H., Dessalegn, Y. and Mohammed, W. (2016). Influence of mulching and varieties on growth and yield of tomato under polyhouse. Journal of Horticulture and Forestry, $8: 1-11$.

Zhang, X.S., Liao, H., Chen, Q., Christie, P., Li, X.L. and Zhang, F.S. (2007). Response of tomato on calcareous soils to different seedbed phosphorus application rates. Pedosphere, 17(1): 70-76. 